\title{
THE EFFECT OF ADOPTION OF INNOVATION ON THE PERFORMANCE OF MICRO AND SMALL ENTREPRISES OF DRIED FISH PROCESSING IN BENGKULU CITY
}

\author{
January Rizki")1, Heni K Suwarsinah"**), and Wahyu Budi Priatna*) \\ *) Department of Agribusiness, Faculty of Economics and Management, IPB University \\ Jl. Agatis, IPB Dramaga Campus, Bogor 16680, Indonesia \\ **) School of Business, IPB University \\ Jl. Raya Pajajaran, Bogor 16151, Indonesia
}

\begin{abstract}
This research aimed to analyze the influence of the characteristics of innovation, internal and external factors to the adoption of innovation and analyze the influence adoption of innovation on the performance of small micro enterprises (MSEs) processing of dried fish in the city of Bengkulu. The influence of the adoption of innovation and the factors that influence the performance of the analysis was done by using SEM (Structural Equation Model). The results showed that the innovation of dried fish processing in Bengkulu City, which is the use of para-para tool and packaging, has the characteristics of relative advantages, compatibility, complexity, trialability, and good observability. Innovation has a low level of complexity by a simpler way of usage than others. Individual characteristics of dried fish artisans have a significant positive effect on the adoption of innovation. The largest contributing variable that reflects individual characteristics is training. The business characteristic variable does not affect the adoption of innovation because of the increasing characteristics of the business requirements, which demands better innovation from the current ones. The environmental drive variable has no significant effect on the adoption of innovation. Although high competition variables reflect environmental variables, competitors from outside the region have their own market share. Government support variables have a significant positive effect on the adoption of innovation. The adoption of innovation has a significant effect on the performance of dried fish processing MSEs in Bengkulu City, where the para-para indicator has bigger contribution than the packaging and the productivity variable has a bigger effect than the sales in reflecting the performance variable of MSE's dried fish processing in Bengkulu City.
\end{abstract}

Keywords: characteristics of innovation, adoption of innovation, business performance, SEM, MSE

\begin{abstract}
Abstrak: Penelitian ini bertujuan untuk menganalisis pengaruh karakteristik inovasi dan faktor internal dan eksternal terhadap adopsi inovasi dan menganalisis pengaruh adopsi inovasi terhadap kinerja usaha mikro kecil (UMK) pengolahan ikan kering di Kota Bengkulu. Pengaruh adopsi inovasi dan faktor yang mempengaruhinya terhadap kinerja dilakukan dengan menggunakan analisis SEM (Structural Equation Model). Hasil penelitian menunjukan bahwa inovasi pengolahan ikan kering di Kota Bengkulu yaitu penggunaan alat para-para dan kemasan memiliki ciri keuntungan relatif, kompatibilitas, kompleksitas, triabilitas, dan observabilitas yang baik. Inovasi memiliki tingkat kerumitan yang rendah dengan cara penggunaan yang lebih sederhana dari cara lain. Variabel yang berkontribusi paling besar yang merefleksikan karakteristik individu adalah pelatihan. Variabel karakteristik usaha tidak berpengaruh terhadap adopsi inovasi karena karakteristik usaha yang semakin meningkat memerlukan inovasi yang lebih baik lagi dari inovasi saat ini. Variabel dorongan lingkungan tidak berpengaruh signifikan terhadap adopsi inovasi. Walaupun variabel persaingan tinggi dalam merefleksikan variabel dorongan lingkungan, namun pesaing dari luar daerah memiliki pangsa pasar sendiri. Variabel dukungan pemerintah berpengaruh positif signifikan terhadap adopsi inovasi. Adopsi inovasi berpengaruh signifikan terhadap kinerja UMK pengolahan ikan kering di Kota Bengkulu, di mana indikator para-para memiliki kontribusi lebih besar dari pada kemasan dan variabel produktivitas berpengaruh lebih besar dari pada penjualan dalam merefleksikan variabel kinerja UMK pengolahan ikan kering di Kota Bengkulu.
\end{abstract}

Kata kunci: karakteristik inovasi, adopsi inovasi, kinerja usaha, SEM, UMK

\footnotetext{
${ }^{1}$ Corresponding author:

Email: januaririzky@yahoo.com
} 


\section{INTRODUCTION}

Indonesia is a maritime country with its two-thirds area consisting of oceans. Indonesia has the secondlongest coastline in the world that can be utilized for the development of maritime industries. This power is the great potential to advance the economy (Hartono, 2015). One industry that can be developed is the fish processing industry.

Activities of the fish processing industry in Indonesia include drying or polishing, canning, freezing, fermentation, suppressing, fish jelly processing, fresh producthandling, and others. Thereare many competitors in the fish processing field. One of the impacts is the emergence of various types of fish processing products both from domestic and foreign countries that have good quality and attractive packaging using sophisticated technology. Thus, companies that still want to survive and do not want to be eliminated from the competition of business ventures must be sensitive to the changes that are vulnerable to occur. The emergence of competitors causing businesses who can compete will be more advanced and those who cannot compete will be left behind. One way to be able to compete is by doing innovation. Continuous innovation allows a business to increase the competitiveness of their products.

Innovation is the foundation for developing entrepreneurship and as a specific tool of entrepreneurship. Innovation is an idea, practice, or object that is considered new by individual units (Rogers, 2003) and can be a source of competitive advantage compared to competitors (Mc. Grath et al. in Wijayanti and Puspitasari, 2010). Innovation is also one of the factors that determine the business performance to improve product quality that affects the performance of the business, namely market share, sales, price, and profitability (Hartini, 2012). Innovation will not be useful without adoption. However, not all innovations can be accepted and adopted by every individual. Several things can affect the adoption of innovations, namely: characteristics of innovation (Serah, 2014; Harinta, 2011; Alam et al. 2011; Subagiyo et al. 2005); internal factors, which are the individual characteristics (Soekartawi, 2005) and internal organization/ enterprises; external factors which are environments and government support (Suharti et al. 2013).
Innovations in fish processing include technological innovations, product innovation, and packaging innovations. Innovations in processing technology that had been achieved namely the use of machines or new technologies such as the use of fish drying equipment with the greenhouse effect (Sulaiman et al. 2015). Product innovation is, for example, creating a new processed type to add value to products. Packaging innovations are achieved by attractive packaging models to improve sanitation and hygiene (Rahmawati, 2008).

There is as many as 259 fish processing unit in Bengkulu which conduct salting or drying process. Dried fish products in Bengkulu serve as one of the regional flagship products. The average volume of dried fish production by the community is quite high, amounting to $88,219 \mathrm{~kg}$ in the year 2014 (DKP, 2015). The fish processing unit in Bengkulu is still on micro and small scale.

The problems faced by micro and small enterprises concern several issues. The problem of small microprocessing of dried fish in Bengkulu, among others, is that the capability of the profitcreation is relatively small, the ownership of craftsmen capital is still relatively small, the ability and knowledge of craftsmen in the technology implementation is still low, the availability of abundant raw materials is not optimally utilized, product sales price is still low (Asriani et al. 2012). In addition, another problem is to develop the business by improving the performance of the business through the adoption of innovation. Business performance is measured by productivity and sales. Preliminary data showed the average dried fish production in the city of Bengkulu before adopting innovations was about $747 \mathrm{~kg} /$ month (DKP, 2007). The average volume of dried fish production in 2014 was after the adoption of innovation.

The dry fish processing business in Bengkulu has been done in generations. The dry fish processing technique is still done based on the same ways of previous business experience, but there is the use of new tools in the process of crafting. Innovation that has been done by the dried fish craftsmen in Bengkulu is the innovation of Para-para use and the innovation of packaging. Previously, the craftsmen only dry the fish on the beach, while the new product packaging innovations are done in the last six years. 
The purposes of this research are 1) analyzing the characteristics of innovations that exist in the MSEs of dried fish processing in Bengkulu city, 2) analyzing the factors that influence the adoption of innovation in the MSEs of dried fish processing in Bengkulu city, 3) analyzing the influence of the adoption of innovation on the performance of the MSEs of dried fish processing in Bengkulu city.

The research was conducted in the city of Bengkulu and the target was the dried fish processing MSEs that have adopted innovations. Models are built related to the adoption of innovation and business performance. The adoption of innovations is measured by the innovation of the use of the para-para as the drying place and the packaging innovations. The adoption of innovations in this research is influenced by the characteristics of innovation, internal factors, and external factors, while the performance of businesses include productivity and sales that are determined based on previous research, as well as analyzing how the adoption of innovation affects business performance. The data analysis tool is Structural Equation Modelling (SEM) analysis.

\section{METHODS}

The research was conducted in Malabero district and Kandang Mas district, Bengkulu City. The study took place in May-June 2015. The data used is secondary data, namely the characteristics of dried fish craftsmen, the characteristics of innovation, individual factors, business factors, environmental factors, adoption of innovations, influence of adoption and performance of the business; as well as primary data, namely the number of fish processing units (UPI) and the production of dried fish in Bengkulu province. The sampling in this research is done by a purposive sampling technique that is dried fish craftsmen who have adopted para-para and packaging innovation. The number of respondents was 130 samples.

The methods of analysis used are data analysis and SEM. Descriptive analysis is used to describe the characteristics of innovations that have been adopted by the dried fish craftsmen, internal factors (individual characteristics and characteristics effort), and external factors (environmental encouragement and government support). Each variable is indicated by a positive statement that has a scale. The scale used in the study was the Likert scale of 1-5 (strongly disagree - strongly agree). SEM analysis (Structural Equation Modelling) is used to determine the influence of the characteristics of innovation, internal and external factors to the adoption of innovation and the influence of innovation adoption on the business performance with the help of LISREL 8.30 software. The SEM procedure begins with the tabulation of the interview data in the form of questionnaires using MS Exel 2010 software, followed by SEM analysis with the following stages: (1) model specifications; (2) model identification; (3) model estimation; (4) model fit test and (5) model respecification.

\section{Questionnaire Validity Test}

The validity of the measurement model is judged based on t-value estimation. If a manifest/indicator variable has a $t$-value of $\geq 1.96$, then the manifest/indicator variable is significant. The validity test is carried out by calculating the correlation between each individual indicator variable with the total score. The calculation was processed using the SPSS16 software. Based on the validity and reliability tests, several invalid questions were found, i.e. age variables (X2.1), education (X2.2), experience (X2.3), asset (X3.3), product character (X3.4), and source information availability (X4.3).

\section{Model Fit Test}

The model fit test was performed to evaluate the Goodness Of Fit (GOF) between the data and the model, as well as the validity and reliability of the measurement model. The results of the fit test (Goodness Of Fit) of the structural model in this study was good (Good Fit), because the estimated value corresponded to the Goodness Of Fit criteria, as shown in Table 1.

The continued development in this globalization era requires artisans to innovate if they want the business to stay afloat. In addition, adopting innovation can also improve the performance of the business (Rofiaty et al. 2008). Several factors affect a person adopting innovation, namely characteristics of innovation and individual characteristic factors, business characteristics, environmental encouragement and government support. 
Table 1. Model fit test of the structural equation model

\begin{tabular}{lccc}
\hline Goodness of Fit Measurement & Estimation & Criteria (fit) & Test Result \\
\hline Root Mean square error of Approximation (RMSEA) & 0.065 & $\leq 0.08$ & Good fit \\
Goodness of Fit Index (GFI) & 0.92 & $\geq 0.9$ & Good fit \\
Adjusted Goodness of Fit Index (AGFI) & 0.91 & $\geq 0.9$ & Good fit \\
Normed fit Index (NFI) & 0.88 & $\geq 0.9$ & Marginal fit \\
Non-Normed Fit (NNFI) & 0.91 & $\geq 0.9$ & Good fit \\
Comparative Fit Index (CFI) & 0.94 & $\geq 0.9$ & Good fit \\
\hline
\end{tabular}

The analysis that initiated this research was to analyze the characteristics of innovation based on the assessment of 130 samples of respondents with the provisions that the selected respondents are dried fish artisans who have adopted innovations. Innovations that have been adopted by craftsmen are the innovation of tools (para-para) and packaging. The use of the innovations of the parapara as a place of drying the fish replaced the previous method which only done on the coastal floor that is only placed on canvas sheets. Before adopting the packaging innovations, the craftsmen only sell dried fish in bulk and put them on the basin without any packaging.

In addition to the characteristics of innovation, we also analyzed the individual characteristics, business characteristics, environmental encouragement, and external government support (Subagiyo et al. 2005). The individual characteristics examined in this study are age, education, experience, knowledge, cosmopolitanism, training, and institutional participation (Soekartawi, 2005; Syafril, 2012). The business characteristics used in this research are the size of the business, venture capital, assets, and product characters (Suharti et al. 2013). Environmental factors examined in this study were competition, buyers, availability of information resources, and government support (Suharti et al. 2013).

The adoption of innovations measured in this research is the innovation of tools and packaging innovations. Indicators in the adoption of innovation in this study were the time that the respondents started adopting the para-para and packaging innovation. The relationship of innovation adoption with the business performance was described by Rosli and Sidek (2013), stating that the adoption of innovations has a significant impact on business performance and adoption of innovation can improve business performance. The business performance observed in the dried fish processing MSEs in Bengkulu city were namely productivity (Baldwin in Nursiah and Radhi, 2009) and sales (Darna and Fatimah, 2014).
Through SEM analysis, the relation between the variable of innovation adoption and the variables of characteristics of innovation, individual characteristics, business characteristics, environmental encouragement, and government support will be understood, and the relation between the variable of innovation adoption and the variable of business performance will be revealed. The operational framework chart of this study is shown in Figure 1.

\section{Hypothesis}

Based on the explanation of the framework chart, the hypothesis of this research is as follows:

H1 : There is a significant positive influence on the characteristics of innovation with the adoption of innovation in dried fish processing MSEs in Bengkulu city.

$\mathrm{H} 2$ : There is a significant positive influence on individual characteristics with the adoption of innovations in dried fish processing MSEs in Bengkulu city.

H3 : There is a significant positive influence of business characteristics with the adoption of innovations in dried fish processing MSEs in Bengkulu city.

H4 : There is a significant positive influence on environmental encouragement with the adoption of innovations in dried fish processing MSEs in Bengkulu city.

H5 : There are significant positive influences of government support with the adoption of innovations in dried fish processing MSEs in Bengkulu city.

H6 : There is a significant positive influence on the adoption of innovation with business performance in dried fish processing MSEs in Bengkulu city. 


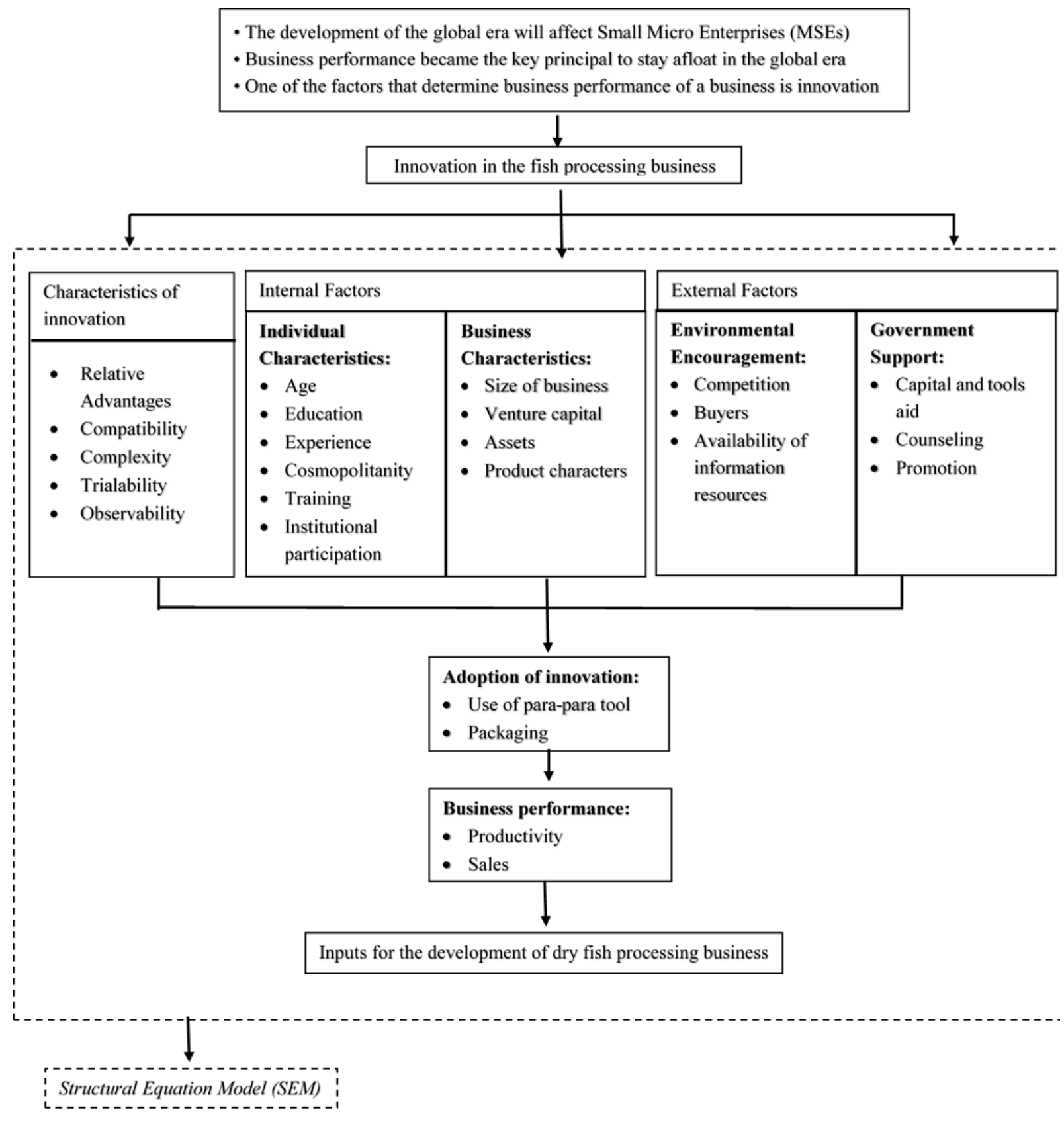

Figure 1. Framework research

\section{RESULTS}

\section{Characteristics of the Business}

The dried fish processing business in Bengkulu city is conducted on a micro and small scale. The process is done by people who are located around coastal areas, especially in Teluk Segara village Malabro subdistrict and Kandang Mas village Kampung Melayu subdistrict. The raw materials used by dried fish processors are fresh fish and salt. Craftsmen acquire fresh fish directly from TPI (fish auction place) or directly from fishermen. The production process of dried fish is carried out in several phases, namely: (1) fish cleansing, (2) cutting, (3) washing, (4) salting, (5) drying, and (6) packing. The capital source of the dried fish processing business in Bengkulu is $91.5 \%$ derived from personal capital. The number of dried fish processing workers in Bengkulu city with $1-3$ personnel is $80.8 \%$. The result of the production of dried fish processing in Bengkulu city at most between $150-999 \mathrm{~kg} / \mathrm{month}(67 \%)$. From the business capital that tends to be small and derived from the personal, the craftsmen are able to produce a lot of dried fish and in accordance with the issued capital, although the scale of business is still relatively small micro-enterprises. 


\section{Characteristics of the Dried Fish Craftsmen}

Characteristics of the business actors are required to create the portrait of respondents associated with their innovative abilities, business management capabilities and the ability to utilize widespread business opportunities (Suharyono et al. 2010). The dried fish craftsmen in Bengkulu city is dominated by men $(66.15 \%)$ and at an average age of $18-40$ years (early adulthood). According to Sutarto (2008), business people who have a young age are more innovative than older people. Dried fish craftsmen in the city of Bengkulu have a low education level that is $60 \%$ of them are middle school graduates. The low education level such as high school graduates is still unable to utilize banks and market cooperatives to get capital loans to develop business, which limits them in the innovation and implementation of the optimal HR development program (Suharyono et al. 2010). Most of the dried fish craftsmen in Bengkulu City (43.08\%) have conducted their business for $1-5$ years. The dried fish business has just rapidly grown in the past seven years, so a lot of new craftsmen (41.54\%) had just started the business and joined the group in the past 1-2 years.

\section{Factors Influencing Adoption of Innovation on the Dried Fish Processing in Bengkulu City}

Description of the adoption of innovations and the performance of dried fish business is evaluated through the assessment of respondents to the variable indicators (manifest) of the characteristics of innovation, internal factors (individual characteristics and business characteristics) and external factors (environmental encouragement and government support), as well as variable indicators (manifest) of the adoption innovation variable and business performance. Those variables are the performance overview of the dried fish processing business in Bengkulu.

\section{Characteristics of Innovation}

The characteristics of innovations observed in this study include relative gains, compatibility, complexity, trialability, and observability, based on Rogers's theory (2003). In terms of relative advantages, the para-para innovation that has been adopted by the dried fish craftsmen in the city of Bengkulu is concluded in a high category. That means the para-para innovation have a good profit in terms of cost and drying time. The compatibility of the para-para innovation is deemed very good, meaning it has good social value and suitable for the needs of the craftsmen. In terms of environmental suitability and environmentally-friendly aspect, assessment of respondents using para-para resulted in as many as 100 percents of respondents agreed that the use of para-para is suitable for the business environment and does not damage the environment. The use of parapara only requires a slightly wider land to place it. The para-para characteristics of the dried fish processing business in the city of Bengkulu belong to a very high category. It means that it is a good innovation because it is easily usable. Respondents' assessment of the trialability level belongs to the high category. It means that it is a good innovation because it can be tested easily on a small scale. Assessment of the trialability of innovation of para-para in dried fish processing business in the city of Bengkulu, it has a low-level risk or almost zero risks. Respondents' assessment of the characteristics of innovation observability of parapara belongs to the high category. It means that people can see the result of using the innovation, that it will increase the production of dried fish.

The relative advantage of packaging innovations that have been adopted by dried fish craftsmen in Bengkulu city belongs to the high category. That is, by adopting packaging innovations craftsmen can obtain a good profit. In this case, it is in terms of the appeal of buyers and the number of sales. The compatibility characteristics of packaging innovations adopted by dried fish craftsmen in Bengkulu city belong to the high category. Packaging innovations are needed by dried fish craftsmen. Hardiani et al. (2012) stated that the packaging is the top marketing tool that is directly facing the consumer, therefore the packaging innovations are good if adopted by the dried fish craftsmen in the city of Bengkulu. The complexity characteristic of the packaging innovations belongs to the high category. This means that the packaging can easily be done by dried fish craftsmen in Bengkulu city. The characteristics of the trialability of packaging innovations that have been adopted by dried fish craftsmen in Bengkulu city belongs to the high category. The respondent's assessment of the packing test statement does not take a long time. The characteristic observability of packaging innovations adopted by dried fish craftsmen in Bengkulu city belongs to the high category. Dried fish craftsmen can observe directly the impact of the use of this packaging innovations, both in terms of price and sales. 


\section{Internal Factors}

The internal factors in this study are grouped into two, namely individual characteristics and business characteristics. The age and cosmopolitanism level of dried fish craftsmen belong to the high category. However, in the cosmopolitanism characteristics, the high category was from the "slightly disagree" statement, which means that the dried fish craftsmen in Bengkulu are not looking for information outside of the environment. Training in the dried fish processing business belongs to the medium category. Although the training was rarely conducted, $36.92 \%$ of respondents were actively asking questions during training. It shows that the dried fish craftsmen were enthusiastic about the training material and their curiosity was quite high. In addition, group activity belongs to the medium category. Craftsmen were quite active in group activities since it made them easier to get some assistance and sales information.

Business characteristics are explained by the indicator variables of business size, business capital, assets, and product characters. Product character indicators are the highest category amongst the characteristic variables. The size of the business belongs to the high category with the highest percentage of $80 \%$. Size of business on the dried fish processing in Bengkulu city are in the small micro scale. Although the scale of the dried fish processing business is micro and small, they can still adopt the para-para and packaging innovations. This is because the use of the tools is simple, easy to obtain and not so expensive.

\section{External Factors}

The external factors in this study were grouped into two, namely environmental encouragement and government support. The variable indicators of environmental drive averages in the high category. However, if associated with the cosmopolitanism, dried fish craftsmen are still not doing good, because the craftsmen are mostly only searching from the surrounding environment. Dried fish craftsmen also seldom obtain information from the counselors, because counseling is very rare in dried fish business in the city of Bengkulu.
The government support variables are still lacking in terms of capital, outreach, and promotion. So far, government support in terms of counseling is very lacking, most of the counseling is conducted for the fishermen, and very rarely for the dried fish craftsmen. Situmorang (2008) stated that effective marketing can be done with promotional activities and the establishment of a business network that can facilitate the dissemination of information about government programs.

\section{Analysis of Structural Equation Model (SEM)}

The Structural Equation Model (SEM) is a statistical technique used to analyze the relationship between latent variables and observed variables (indicators), or the relationship between the endogenous and exogenous latent variables. SEM also illustrates the relationship between the latent and manifest variables. The measurement model illustrates the relationship between an exogenous latent variable and an endogenous latent variable with its indicator variable. The relationship shown is how strong the indicator variable is in measuring each of its latent variables. The exogenous latent variables set out in this study are characteristic of innovation (X1), individual characteristics (X2), business characteristics (X3), environmental encouragement (X4), and government support (X5). The latent variables of the endogenous established in this study are the adoption of innovation (Y1) and the business performance (Y2). Diagram of SEM cross model based on T-value estimation in Figure 2. Diagram of SEM cross model based on Standardized Solution estimation in Figure 3.

The results of the model respecification in the study still have a negative $t$-value, but the presented figure is the best result of the respecification. A variable is said to have good validity when the latent variable has a t-value of $\geq 1.96$ in a significant level of 5\% (Igbaria et al. 1997 in Wijanto, 2008). There are two variables in this study that have a t-value of less than 1.96, those are latent variables of exogenous characteristics of the business and variable exogenous environmental impulses with a t-value value of 1.16 , this value is the best value after respecification. The result of the fit test estimation on the model after the respecification can be seen in Table 2. 


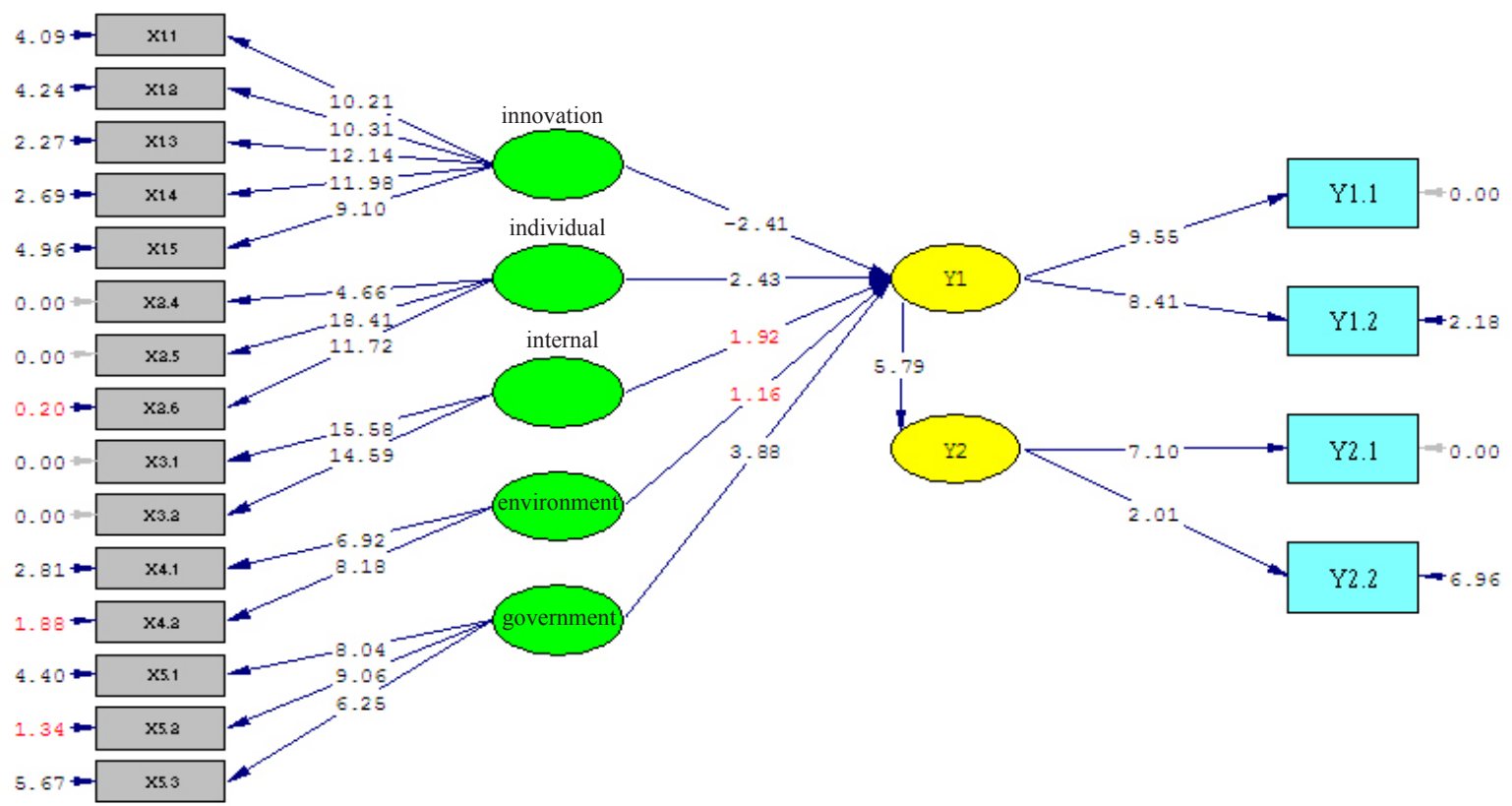

Chi-Square=198.33, df=128, P-value=0.00007, RMSEA $=0.065$

Figure 2. Diagram of SEM cross model based on T-value estimation

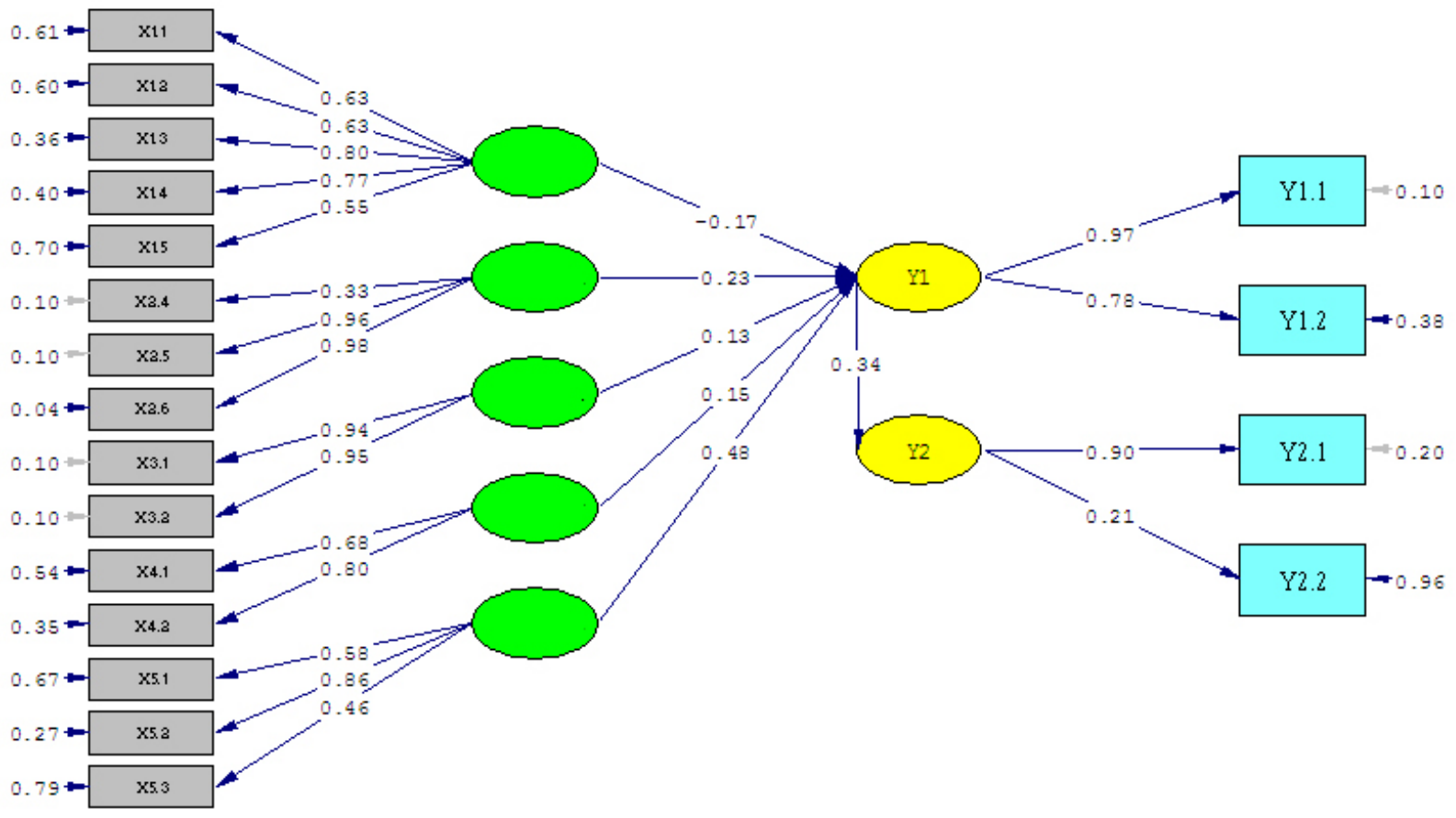

Chi-Square $=198.33, \mathrm{df}=128, \mathrm{P}-\mathrm{value}=0.00007, \mathrm{RMSEA}=0.065$

Figure 3. Diagram of SEM cross model based on Standardized Solution estimation 
Table 2. Evaluation of structural model coefficient of respecification results

\begin{tabular}{lccc}
\hline Path & Coefficient & T-value Computed & Conclusion \\
\hline Characteristics of innovation $\rightarrow$ Adoption of innovation & -0.17 & -2.41 & significantly negative \\
Individual characteristics $\rightarrow$ Adoption of innovation & 0.23 & 2.43 & significantly positive \\
Business characteristics $\rightarrow$ Adoption of innovation & 0.13 & 1.92 & not significant \\
Environmental encouragement $\rightarrow$ Adoption of innovation & 0.15 & 1.16 & not significant \\
Government support $\rightarrow$ Adoption of innovation & 0.48 & 3.88 & significantly positive \\
Adoption of innovation $\rightarrow$ Business performance & 0.34 & 5.79 & significantly positive \\
\hline
\end{tabular}

Description: significant at the 5\% level "(T-value $>1.96$ )

The innovation characteristic variable has a significant negative effect on the adoption of innovations where the coefficient value of -0.17 and t-value of -2.41 , meaning that the higher the characteristics of innovation makes the adoption of innovation decreases. The highest innovation characteristic is reflected by the complexity of innovation with the loading factor value of 0.80 and the lowest innovation characteristic is reflected by the characteristics of observability with the loading factor value of 0.55 . However, although the characteristic of innovation is already good (high and very high category), the dried fish craftsmen in the city of Bengkulu still tend to be slow in adopting the innovations of parapara and packaging.

The individual characteristic variable has a significant positive influence on the adoption of innovations in dried fish processing efforts in the city of Bengkulu. This means the higher characteristic of dried fish craftsmen individuals, the more increased the adoption of innovation. The highest individual characteristic is reflected by the training variable with the loading factor value of 9.98. That is, the dried fish craftsmen in Bengkulu City is very enthusiastic about every training held by the related agencies. Therefore, the better the individual characteristics are, the more increased the adoption of innovation. According to Cuganesan (2005), individual characteristics are human resources to product innovation, and it is the primary key of an innovation.

Variable characteristic of dried fish processing business has no effect on the adoption of innovations in dried fish processing business in the city of Bengkulu (reject $\mathrm{H} 3$ ), with a coefficient of 0.13 and t-value of 1.92 . That is, the higher the business characteristics, the lower the innovation adoption in the dried fish processing in the city of Bengkulu, since the applied innovation is still very simple. The increasing characteristics of the business require better innovation than the current ones. For example, the larger business size requires increased production capacity, which demands more adequate innovations to make the production process more effective and not only depend on nature.

The variable of environment encouragement has no significant effect on the adoption of innovation. That is, while environmental encouragement is increased, the adoption of innovations tends to decline. The environmental encouragement manifest variable consists of competition, buyers and availability of information sources. The competition manifest variable reflects the environmental encouragement with the lowest loading factor value of 0.68 . This is because most of the dried fish craftsmen in Bengkulu City sells processed results within the area, although there are some of them that are sold out of the area, the quantity is very small. In addition, dried fish craftsmen in the city of Bengkulu have their own market share, namely based on the type of fish sold. Competitors who enter the city of Bengkulu sell dried fish products with different types of fish, so consumers still buy the type of dried fish sold by craftsmen in the city of Bengkulu. Thus, the increasing number of competitors would not affect the adoption of innovation and sales.

The variable of government support has a significant positive influence on the adoption of innovation. The influence of government support for adoption is considerably high. The government has an important role in promoting the adoption of innovation through regulation, by implementing guidelines and providing financial assistance and policies (Hameed and Counsell, 2012; Mai and Phoung, 2013; Grazhdani, 2013). That is, if government support such as funds and facilities, counseling, and promotion to the dried fish processing business in the city of Bengkulu increased, then the adoption of innovations in dried fish processing efforts are likely to increase. 
The results of the SEM analysis of the model shows that the latent variable of the adoption of innovation affects business performance. That is, the adoption of innovations in the fish processing business significantly affect business performance. The para-para variable contributes significantly to reflect the adoption of innovation compared to the packaging variable with the loading factor value of 0.97 . Variable that contribute significantly to reflect the performance is productivity variable compared with the sales variable with the loading factor value of 0.90 . This means that by adopting para-para and packaging innovation, the productivity of MSEs dried fish processing is increased compared to the dried fish sales performance in the city of Bengkulu.

\section{Managerial Implications}

Based on the results of the research, local governments and related agencies need to pay special attention to the dried fish craftsmen either from the provision of funds assistance, counseling about the more advanced technology of dried fish processing which can be applied to the business environment, and provide training and motivation to craftsmen to improve their ability to cultivate the business with appropriate innovations, for the sake of developing the dried fish processing business in the city of Bengkulu.

\section{CONCLUSIONS AND RECOMMENDATIONS}

\section{Conclusions}

The study of the characteristics of innovation in MSEs dried fish processing in Bengkulu City shows that para-para and packaging innovation is characterized by a relative advantage, compatibility, complexity, trialability, and good observability. This is evident from the value of high and very high categories. The innovation has a low level of complexity in a way that is simpler than the use of other means, easy to obtain, easy to use, easy to make and easy to apply.

Factors influencing the adoption of innovations in the MSEs dried fish processing in the city of Bengkulu are internal and external factors. Internal factors consist of individual characteristics and business characteristics, while external factors are environmental encouragement and government support. Individual characteristics of dried fish craftsmen have a significantly positive influence on the adoption of innovation. The most contributing variable that reflects the individual characteristics is the training variable. Business characteristics have no effect on the adoption of innovation, because if the business characteristics are increasing, it needs better innovation than the current ones. Environmental encouragement variables have no significant effect on the adoption of innovation, because despite the high competitive variables that reflected the environmental encouragement variables, each competitor from outside the region has its own market share. The government support variable has a significant positive impact on innovation adoption. That is, if government support such as funds and facilities, counseling, and promotion to the dried fish processing business in the city of Bengkulu increased, then the adoption of innovations in dried fish processing efforts are likely to increase. The lowest contributions that reflect the government support variables are promotion variables.

The adoption of innovations significantly affects the performance of MSEs dried fish processing in the city of Bengkulu, where the para-para variable has a greater contribution than the packaging variable, and the productivity variable contributes larger than the sales variable in reflecting the performance of the MSEs dried fish processing in Bengkulu.

\section{Recommendations}

Based on the research results, our suggestions are as follows: (1) It is advised that the local government and related agencies provide counseling and training to the dried fish craftsmen to provide information regarding innovation to improve the performance of MSEs dried fish processing; (2) The government support will increase innovation adoption, by means of giving assistance, counseling, and promotion. However, the promotion on the MSEs dried fish processing is still lacking. Therefore, it is advised that the government further promote the MSEs dried fish processing, for example by introducing this business through websites and certain events, so that the MSEs dried fish can be more widely known and developed; (3) Further studies can focus on analyzing other innovations that may exist in the dried fish processing business and analyze the relationship between adoption of innovation and its impact on business performance, such as income and market share. 


\section{REFERENCES}

Asriani, Mulyasari, Sukiyono, Nabiu. 2012. Analisis Nilai Tambah dan Peluang Pengembangan Usaha. Seminar Nasional Ekonomi Kreatif 2013.

Cuganesan S. 2005. Intellectual capital-in-action and value creation: a case study of knowledge transformation in innovation project. Journal of Intellectual Capital 6(3): 357-373. https://doi. org/10.1108/14691930510611102.

Darna, Fatimah. 2014 Model peningkatan kinerja melalui peningkatan kapabilitas inovasi pada uusaha kecil dan mikro (UMK) yang dikelola oleh kaum wanita. http://lppm.unmas.ac.id/wpcontent/uploads/2014/06/39-DARNA_KL-1.. pdf [25 Jan 2015].

[DKP] Dinas Kelautan dan Perikanan Provinsi Bengkulu. 2013. Potensi, tingkat pemanfaatan dan peluang pengembangan usaha perikanan tangkap di Provinsi Bengkulu tahun 2012. Bengkulu: DKP

Hardiani N, Sadiah H, Aryanti. 2012. Inovasi desain kemasan lempok durian sebagai strategiuntuk meningkatkan usia simpan dan daya jual produk di Kalimantan Selatan. Journal Prestasi 1(2):3948.

Hameed MA, Counsell S. 2012. Assessing the influence of environmental and ceo characteristics for adoption of information technology in organizations. Journal of Technology Management \& Innovation 7(1):64-84. https:// doi.org/10.4067/S0718-27242012000100005.

Harinta W. 2011. Adopsi inovasi pertanian di kalangan petani di Kecamatan Gatak Kabupaten Sukoharjo. Jurnal Agrin 15(2):164-174.

Hartini S. 2012. Peran inovasi: pengembangan kualitas produksi dan kinerja bisnis. Jurnal Manajemen dan Kewirausahaan 14(1): 63-90. https://doi. org/10.9744/jmk.14.1.83-90.

Hartono. 2015. Kemenperin dorong pembangunan industri berbasis maritim. www.kemenperin. go.id [07 Apr 2015].

Grazhdani. 2013. An analysis of factors affecting the adoption of resource conserving agricultural technologi es In Al- Prespa Park. Paper Natura Montenegrina 12(2): 431.

Mai QN, Phuong VN. 2013. The impact of external environment, technology and innovation capacities, and leadership development on organizational performance in food industry. a qualitative study of food enterprises in Ho Chi Minh City, Vietnam. International Journal of Business, Humanities and Technology 3(4):4960.

Nursiah, Radhi F. 2009. Pengaruh penerapan strategi inovasi terhadap kinerja operasional. Jurnal Akuntansi dan Manajemen 20(2): 69-77.

Rahmawati, Fitri. 2008. Pengembangan Usaha Hasil Olahan Ikan Guna Meningkatkan Pendapatan Masyarakat Pesisir Pantai di Daerah Gunung Kidul. Seminar Nasional Tahunan V Hasil Penelitian Perikanan dan Kelautan, 26 Juli 2008

Rofiaty, Idrus M, Ubud S, Dwiatmadja C. 2008. Pengaruh kondisi lingkungan, perilaku berbagai pengetahuan, proses perencanaan strategi, terhadap inovasi dan kinerja (studi pada UKM sentra kerajinan kulit di Jawa Timur). Jurnal Aplikasi Manajemen 8(3):764-775.

Rogers EM. 2003. Diffusion Of Innovations fifth Edition. New York: The Free Press. A Division of Simon \& Schuster, Inc.

Rosli M, Sidek S. 2013. The Impact of Innovation on the PerformanceofSmallandMediumManufacturing Enterprises: Evidence from Malaysia. IBIMA Publishing. Journal of Innovation Management in Small \& Medium Enterprise 2013(2013):116. https://doi.org/10.5171/2013.885666.

Situmorang J. 2008. Strategi UMKM dalam menghadapi iklim usaha yang tidak kondusif. Jurnal Infokop: Media Pengkajian Koperasi Usaha Kecil dan Menengah 16: 87-101.

Soekartawi. 2005. Pinsip Dasar Komunikasai Pertanian. Jakarta: UI-Pers

Siyamtinah, Sulistyo, Rahmani. 2011. Model peningkatan kinerja melalui kapabilitas Inovasi pada UKM di Semarang. Seminar Nasional Ilmu Ekonomi Terapan. Fakultas Ekonomi UNIMUS

Sulaiman I, Mulana F, Chairani S, Syafruddin. 2015. Adopsi dan inovasi alat pengering ikan kayu di Desa Nelayan Lampulo Banda Aceh. Jurnal Teknologi dan Industri Pertanian Indonesia 7(2). https://doi.org/10.17969/jtipi.v7i2.3280.

Subagiyo, Rusidi, Sekarningsih R. 2005. Kajian faktor-faktor sosial yang berpengaruh terhadap adopsi inovasi usaha perikanan laut di Desa Pantai Selatan Kabupaten Bantul, DIY. Jurnal Pengkajian dan Pengembangan Teknologi Pertanian 8(2):301-315.

Suharti, Sugiono, Purwati. 2013. Faktor-faktor pendorong dan penghambat inovasi teknologi 
pada usaha kecil (Studi padaProdusen Tempe di Jawa Tengah, Indonesia). Journal \& Proceeding Universitas Jendral Soedirman 3(1):1-13.

Suharyono, Hubeis, Djohar, dan Hartoyo. 2010. Analisis kapabilitas organisasi dan lingkungan usaha terhadap kinerja bisnis dan implikasinya bagi pengembangan usaha di pasar tradisional spesifik PD pasar jaya. Jurnal Manajemen dan agribisnis (JMA) 7(1):27-47.

Sutarto. 2008. Hubungan Sosial Ekonomi Petani dengan Tingkat Adopsi Inovasi Teknologi Komoditas Jagung di Sidoharjo Wonogiri. Jurnal Gritexts 24:1-12.

Serah T. 2014. Pengaruh karakteristik inovasi sistem sosial dan saluran komunikasi terhadap adopsi inovasi teknologi pertanian. Jurnal Magister Manajemen 2014:1-12.

Soekartawi. 1988. Prinsip Dasar Komunikasai Pertanian. Jakarta: UI-Pers

Syafril D. 2002. Hubungan karakteristik petani dan jaringan komunikasi dengan adopsi inovasi teknologi sistem usaha pertanian jagung [tesis]. Bogor: Institut Pertanian Bogor.

Wijayanti, Puspitasari I. 2010. Inovasi pada usaha kecil dan menengah di DIY: tipe, sumber informasi, dan akses teknologi. Jurnal manajemen dan Bisnis 1(2010): 33-52

Wijanto. 2008. Structure Equation Modeling dengan LisreL 8.8 Konsep dan Tutorial. Jakarta: Graha Ilmu. 